\title{
Economic analysis for marine protected resources management: Challenges, tools, and opportunities
}

\author{
Fonner Robert ${ }^{1,}{ }^{\star}$, Bellanger Manuel ${ }^{2}$, Warlick Amanda ${ }^{3}$
}

\begin{abstract}
${ }^{1}$ Northwest Fisheries Science Center, 2725 Montlake Blvd. East, Seattle, WA, 98112, USA
2 Ifremer, RBE-Economie Maritime, UMR 6308 AMURE, Univ Brest, CNRS, Rue Dumont d'Urville, Plouzane, 29280, France

${ }^{3}$ School of Aquatic and Fishery Sciences, University of Washington, 1122 NE Boat St, Seattle, WA, 98105, USA
\end{abstract}

* Corresponding author : Robert Fonner, email address : robby.fonner@noaa.gov

\begin{abstract}
:
Economic analysis is well suited to inform protected resources management in marine and coastal environments. The purpose of this review is to provide a connection between the challenges facing managers of marine protected resources and specific forms of economic analysis that can help address them. We identify and illustrate several common protected resources management challenges including scarcity in conservation resources, scientific uncertainty, and designing policies to promote species conservation and recovery. We then survey relevant economic tools and identify opportunities for informing marine protected resources management. We conclude by discussing important considerations for applying economic analysis to inform marine protected resources management.
\end{abstract}

\section{Highlights}

- Several challenges to protected resources management in marine and coastal environments are reviewed and illustrated. The current role of economic analysis in marine protected resources management is reviewed. Tools for informing marine protected resources management are surveyed and aligned with identified management challenges.

Keywords : Marine protected resources, Economic analysis, Endangered species, Ecosystem-based management 


\section{Introduction}

A myriad of human activities threaten marine ecosystems and their biodiversity (Halpern et al., 2008; McCauley et al., 2015). Addressing these threats requires developing effective management approaches for protecting and conserving imperiled ecosystems. Management approaches that consider social and economic factors, in addition to intrinsic ecological considerations, are more likely to be successful (Long et al., 2015; McLeod et al., 2005; Pikitch et al., 2004).

The purpose of this article is to review economic concepts and tools that can be brought to bear to address common marine protected resources (MPR) management challenges. Prior articles reviewing the economics of protected species management have reviewed literature on the economics of species recovery and conservation generally (Ando and Langpap, 2018), and curated studies on the economics of conservation of protected species in marine and coastal environments specifically (Wallmo et al., 2016). The contribution of this paper with regard to existing literature is twofold. First, we structured this conceptual review to highlight management challenges, and the economic tools available to address those challenges, in order to maximize its usefulness to managers and policy decision-makers. In particular, we identify three common challenges facing MPR managers, and then align the challenges with specific forms of economic analysis that can inform and address those challenges. For context, we illustrate the identified challenges using evidence from the literature and discuss past analyses conducted to address these challenges. Second, our review synthesizes concepts, challenges, and literature specific to protected resources management in marine and coastal environments. These environments can be more complex to manage than terrestrial systems due to their expansive extent, associated challenges associated with studying the underwater environment, and the fact 
that marine ecosystems often span several jurisdictional boundaries (Bayraktarov et al., 2016; Ruckelshaus et al., 2008). Additionally, marine environments have long been associated with issues of open access, and likewise difficulties with establishing and enforcing property rights. For these reasons, findings from literature on the economics of terrestrial protected resources may not apply to marine and coastal environments.

Following this introduction, we identify and illustrate three major MPR management challenges before turning to a review of the current role of economic analysis in MPR management. A survey of the economic tools and methodologies used to address management challenges follows before we conclude by discussing the application of economic analysis for MPR management with respect to the broader species conservation literature.

\section{Marine protected resource management challenges}

This article focuses on three of the major challenges facing MPR managers: allocating scarce funding resources, dealing with scientific uncertainty, and developing effective recovery policies and institutions. In this section, we review these challenges in the context of MPR management practice. While not a comprehensive appraisal of all challenges facing MPR managers, we chose to focus on the three aforementioned challenges because we found evidence of their importance in the literature and because they correspond to economic analysis tools that can help address them.

\subsection{Allocating scarce recovery resources}

The resources available to pursue species conservation are scarce, meaning that resources are insufficient to fund all worthwhile conservation activities. Economic theory predicts this scarcity because MPR conservation exhibits public good characteristics, implying that private decisions over how to use coastal and marine environments will tend to supply inefficiently low levels of 
conservation. Moreover, fundraising for conservation from charities and taxes are expected to be inefficiently low because individuals are able to reap the benefits of conservation without paying their fair share (i.e. the free rider problem) ${ }^{1}$. Likewise, empirical evidence suggests that conservation resources are scarce for maintaining biodiversity globally (Balmford et al., 2003; McCarthy et al., 2012) as well as for supporting national laws for conserving imperiled species (Gerber, 2016; Joseph et al., 2008). Furthermore, current research and conservation efforts are disproportionally focused on terrestrial systems, potentially making resources even scarcer for marine conservation (Di Marco et al., 2017). The Endangered Species Act (ESA) in the United States is a prominent and well-studied species conservation law for which detailed data on funding scarcity is available. We review resource scarcity in the ESA context below but note that this scarcity is prevalent globally, which is reflected in the growing body of literature that deals with how to effectively allocate available resources to achieve conservation objectives (Joseph et al., 2009; Murdoch et al., 2007).

Since the Endangered Species Act (ESA) was enacted in the United States, cumulative ESA listings have grown steadily, with over 2,300 species listed as Threatened or Endangered as of 2019 (USFWS, 2019c). Annual listings averaged over 36 species per year from 1974 to 2018, and ranged from no new listings in 1974 to 129 new listings in 1994 (USFWS, 2019a). Meanwhile, only 54 species have been delisted due to species recovery since enactment of the ESA (USFWS, 2019b), resulting in a significant net increase in listed species over time. Substantial resources are devoted to recovery of ESA-listed species in the US, as evidenced by the over $\$ 30$ billion spent on recovery efforts over the past 25 years. However, the available resources are still insufficient, and less than one-quarter of the funds required for implementing

\footnotetext{
${ }^{1}$ These features of species conservation are noted in Ando and Langpap, 2018
} 
ESA recovery plans are available for undertaking species recovery efforts (Langpap et al., 2018). As of 2016, 24\% of ESA-listed species were in decline and had underfunded recovery plans, while only $12 \%$ of listed species were receiving recovery funding at or above levels specified in their recovery plans (Gerber, 2016). Further, one-quarter of listed species lack a final recovery plan at all and half of all existing recovery plans are more than 20 years old (Malcom and $\mathrm{Li}$, 2018). These figures suggest that the current implementation of the ESA is under pressure from increasing listings, and that current funding levels are not adequate to meet recovery plan goals. If this situation persists, MPR policy makers will increasingly face trade offs between recovery actions, and potentially having to prioritize some species over others (Gerber et al., 2018; Joseph et al., 2009). Cost-effective resource allocation is particularly important for achieving recovery goals in the current climate of increasing resource scarcity, underscoring a need for economic analysis to inform MPR management (Duke et al., 2013).

\subsection{Addressing scientific uncertainty}

Scientific uncertainty can pose a variety of challenges to MPR policymakers and managers. This article focuses on how it complicates the development and evaluation of conservation policies, whose outcomes are inherently uncertain. Scientific uncertainty can also affect which policy instruments are appropriate for a particular management context and reduce the ability of stakeholders to address common pool resource problems through collective action (Libecap, 2014). Reducing scientific uncertainty is possible through allocating resources for research, data collection, monitoring, and enforcement.

Forecasts of uncertain outcomes have economic value because in many cases decision makers' best choices depend on what future conditions materialize. For example, improved predictions of the timing and magnitude of uncertain threats to protected species can both 
improve the effectiveness of measures taken to mitigate threats and reduce the regulatory burden on economic sectors affected by mitigation measures (e.g., Bisack and Magnusson, 2014). Thus, knowledge of the future implies a different optimal choice than when making a naive decision. A simple definition of the value of information compares the economic value of outcomes associated with decisions informed by the information under consideration to the value of outcomes associated with decisions that would have occurred in the absence of the information. There exists a rich empirical literature focusing on the value of information for managing marine resources (Costello et al., 2001; Essington et al., 2018; Hutniczak et al., 2018; Polasky and Solow, 2001) and for MPR specifically (Bisack and Magnusson, 2014; Costello et al., 1998; Huang et al., 2012).

Subsequent discussions of uncertainty in this article focus on prioritizing and adapting research efforts to reduce and manage scientific uncertainty in specific MPR contexts. However, the economic literature also addresses uncertainty in natural resource management more broadly. For example, LaRiviere et al. (2017) characterized different types of uncertainty that arise in natural resource management, evaluated general hypotheses in the literature related to uncertainty, and assessed whether insights or lessons learned are transferable across natural resource contexts.

\subsection{Developing institutional arrangements that promote conservation and recovery}

Developing institutional arrangements that effectively balance tradeoffs between competing stakeholder interests and conservation outcomes also poses challenges to MPR management efforts (Brechin et al., 2002). Institutions include official laws and policies, cultural practices, and societal norms (Ives and Kendal, 2014). Over time scales spanning decades or more, institutional structures evolve according to preferences and values. Societal norms and cultural 
practices are thought to change over centuries, while the institutional environment, including constitutional amendments and legal statutes, typically evolves over decades (Williamson, 2000). On shorter time scales, institutions shape the incentives facing MPR stakeholders, thereby influencing their behavior. For instance, the choice of policy instruments may influence the incentives facing stakeholders, as well as their decision-making (Vatn, 2005). Regulations can leverage individual incentives (e.g., using market-based policy instruments) or they can promote cooperative behavior (e.g., developing co-management arrangements empowering local communities). Moreover, a diverse set of institutions, both formal and informal, likely act in concert to influence the effectiveness of most MPR conservation policies (Crowder et al., 2006; Gopalakrishnan, 2005).

Designing formal institutions (i.e., laws, policies, regulations) for MPR management is challenging because marine species often span multiple jurisdictional boundaries and biomes. MPR management thus typically affects multiple sectors and a wide variety of stakeholder groups. Management regimes for individual sectors often operate under different legal mandates that lack integration across sectors, so that governance structures contain gaps and overlaps that make it difficult to reconcile the interests of various stakeholders and conservation objectives (Young, 2002). In addition, ecosystems containing MPR are often spatially and temporally heterogeneous, which requires flexible and adaptive management institutions (Dietz et al., 2003). Distributional issues may also impede the legitimacy and performance of MPR management institutions or prevent the implementation of new institutional arrangements. If the institutional change is not Pareto improving-- if there are stakeholders that are better off by staying in the previous system--then large aggregate ecological and economic benefits of introducing a policy instrument may not be sufficient to ensure that institutional reform will be successful. 
Understanding stakeholders' objectives and the nature of tradeoffs among them is therefore critical to the development of institutional arrangements that foster marine species conservation (Burgess et al., 2016).

\section{The current Role of Economics in Marine Protected Resources Management}

This section reviews the current use of economic analyses in studying and planning conservation and recovery of imperiled species. We begin by reviewing the well-studied ESA context in the United States before turning to reviewing the application of economics to species recovery in other countries.

The ESA prohibits the consideration of economic factors in species listing determinations. Until recently, the regulations on listing determinations also required that these decisions be made "without reference to possible economic or other impacts". The listing regulations were modified in 2019 to permit reporting of the economic impacts of listing species, though the law still maintains that economic factors should not be considered in listing decisions (Congressional Research Service, 2019). Managers can employ economics to inform other ESA recovery planning and management decisions. For example, critical habitat designations can limit human uses of an area to facilitate species recovery, and the ESA allows exclusion of the proposed critical habitat if the economic benefits of exclusion are sufficiently large, and the exclusion will not lead to species extinction. Federal rules can also compel MPR managers to employ economic analysis when federal actions impact listed species or when regulations have significant economic consequences. These cases involve a net present value comparison of the costs and benefits of an action in accordance with Executive Order 12866 and Executive Order 13563. 
A national review by NOAA economists found that of the 72 economic analyses conducted to support MPR regulatory actions over the a 15 -year period, 1/3 were analyses supporting critical habitat designations (CHDs), and 1/2 evaluated existing or proposed regulations for commercial fisheries (NMFS, 2014). Plantinga et al. (2014) concluded that while current methodologies used to estimate the costs of CHDs are sound from an economic perspective, inherent uncertainty in the impacts that CHDs will have on economic activity makes development of useful estimates difficult. In part owing to this uncertainty, the authors found no evidence that prior CHD economic analyses provided useful information for making exclusion decisions.

Similar to the ESA, laws for endangered species conservation in Europe and Australia consider only ecological factors when making listing decisions but allow for consideration of economic factors when evaluating candidate recovery actions. The Environment Protection and Biodiversity Conservation (EPBC) Act of 1999 is the legal framework for managing threatened species recovery in Australia. Members of the public nominate species and ecological communities for listing, and listing nominations are evaluated by the Threatened Species Scientific Committee based solely on ecological factors (TSSC, 2017). After listing, any action that is likely to significantly impact listed species or communities must undergo an "environmental assessment and approval" process before proceeding. When deciding whether to approve an action, the Environment Minister must consider a broad range of issues, including economic and social matters related to the action (Macintosh and Wilkinson, 2005). For marine and aquatic species, Walsh et al. (2013) found that fish and amphibian taxa are underrepresented compared to mammal and bird taxa, echoing the findings of Metrick and Weitzman (1996) in the ESA context. 
In European Union (EU) countries, the Habitats Directive of 1992 and the Bird Directive of 2009 provide structure for listing imperiled species and habitats, and for developing Natura 2000, a network of protected areas for listed resources. The directives establish a list of threatened resources, and member EU nations are then responsible conserving listed resources through designating protected areas and managing human impacts on listed species. Member countries are required to consider economic factors when planning recovery actions, including the designation of specific protected sites (EU-Commission, 2011).

The Species at Risk Act (SARA) of 2002 governs endangered species management and recovery in Canada. SARA is similar to its American counterpart, the ESA, in that it creates a list of imperiled species, designates habitat areas for protection, and permits consideration of economic factors in developing action plans for species recovery. A key difference, however, is that SARA allows for the consideration of economic impacts as part of species listing decisions (e.g., see Waples et al., 2013). While not a formal component of the listing process, the government conducts a "socioeconomic analysis" prior to listing decisions that amounts to a form of regulatory impact analysis (Mooers et al., 2010). Some authors point to SARA's incorporation of economic factors into listing decisions as a potential future direction for the ESA (e.g., Plantinga et al., 2014). In practice, however, the economic analyses undertaken to support SARA may be limited in scope. In particular, these analyses focus on estimation of local economic impacts ${ }^{2}$ and the benefits of species recovery may be ignored (Adamowicz, 2016). In addition, it is not clear that the socioeconomic analyses undertaken to support SARA appropriately weigh the societal costs of listing. For example, Schultz et al. (2013) found in the

\footnotetext{
${ }^{2}$ Economic impacts are the changes in expenditures, wages, and employment associated with listing decisions. Economic impacts are distinct from measures of total economic value, which are used for formal benefit cost analysis.
} 
case of marine fishes, any predicted listing "cost", or negative regional economic impact, was associated with rejection of proposed listings. Likewise, McDevitt-Irwin et al. (2015) found significant bias against listing marine fish species, and argue for more rigorous economic analysis of listing decisions.

New Zealand's approach to allocating resources for endangered species recovery considers cross-species tradeoffs and provides a contrast to typical, single-species allocation approaches. The approach was proposed by Joseph et al. (2009) and fits within a body of literature that recognizes that conservation resources are scarce, and seeks to maximize return on conservation investments subject to a budget constraint (see Boyd et al., 2015). In particular, Joseph et al. (2009) proposed a project prioritization protocol (PPP) system for prioritizing candidate conservation actions that span New Zealand's endangered species. In essence, the proposed system operationalized the "Noah's Ark" cross-species prioritization framework first proposed by Weitzman (1998), while also accounting for the probability of project success. Significant debate exists in the literature over whether it is appropriate or ethical to consider cross-species tradeoffs in conservation planning (e.g., Brown et al., 2015; Pimm, 2000), however there is emerging evidence that such approaches can improve conservation outcomes (e.g., Gerber, 2016). Likewise, the PPP system garnered local support (Seabrook-Davison et al., 2009) and its application is expanding to other countries (Brazill-Boast et al., 2018). The PPP paradigm for protected resources management deals with a common economic theme, allocating scarce resources, and economics may directly contribute to further development in this area using the tools identified in subsequent sections of this article. 


\section{Economic Tools for MPR Management}

Economics provides analytical models and empirical methodologies for addressing MPR management challenges and informing MPR policies. When MPR policies influence the welfare and behavior of stakeholders, economics and related social sciences provide frameworks for understanding these effects. Economic frameworks for understanding such phenomena include models of human incentives, strategic interactions, cognitive biases, and collective action. Economics also provides tools for quantitatively comparing recovery policies based on their costs and benefits, as well as informing allocations of scientific research and monitoring efforts.

It is beyond the scope of this article to enumerate all forms of economic analysis relevant to MPR conservation and recovery. Instead, we identify a suite of economic tools that can inform MPR management and then organize these tools according to their corresponding research tasks. The tasks, which are reviewed elsewhere in the literature, include developing candidate policies and predicting their effects, estimating stakeholder preferences over candidate policies, and evaluating and prioritizing candidate policies (Ando and Langpap, 2018; Innes et al., 2015; Lew, 2015). Table 1 aligns the research tasks with relevant economic tools, the MPR management challenges they address, and relevant literature. 
Table 1.

Economic tools for planning marine protected resource management and relevant literature

\begin{tabular}{|c|c|c|c|c|c|c|}
\hline Research task & $\begin{array}{c}\text { Relevant } \\
\text { economic tools }\end{array}$ & Use of tool & $\begin{array}{l}\text { Allocating } \\
\text { scarce recovery } \\
\text { resources }\end{array}$ & $\begin{array}{l}\text { Addressing } \\
\text { scientific } \\
\text { uncertainty }\end{array}$ & $\begin{array}{l}\text { Developing } \\
\text { institutional } \\
\text { arrangements }\end{array}$ & Relevant literature \\
\hline \multirow{4}{*}{$\begin{array}{l}\text { Developing } \\
\text { policy } \\
\text { instruments and } \\
\text { understanding } \\
\text { their effects }\end{array}$} & $\begin{array}{l}\text { Market-based } \\
\text { policy } \\
\text { instruments }\end{array}$ & $\begin{array}{l}\text { Incentivize behavior that } \\
\text { advances conservation goals }\end{array}$ & $\checkmark$ & & $\checkmark$ & $\begin{array}{l}\text { Innes et al. 2015, Holland and } \\
\text { Jeannot 2012, Bisack and } \\
\text { Sutinen } 2006\end{array}$ \\
\hline & $\begin{array}{l}\text { Causal policy } \\
\text { analysis }\end{array}$ & $\begin{array}{l}\text { Understand the effect past } \\
\text { policies had on outcomes of } \\
\text { interest }\end{array}$ & $\checkmark$ & & $\checkmark$ & $\begin{array}{l}\text { Athey and Imbens 2017; } \\
\text { Ferraro et al. 2019; Sills et } \\
\text { al. } 2018\end{array}$ \\
\hline & $\begin{array}{l}\text { Bioeconomic } \\
\text { modeling }\end{array}$ & $\begin{array}{l}\text { Optimal control of management } \\
\text { problems, dynamic policy } \\
\text { simulation }\end{array}$ & $\checkmark$ & $\checkmark$ & & $\begin{array}{l}\text { Chan and Pan 2016; Conrad } \\
\text { and Rondeau 2015; } \\
\text { Sanchirico et al. } 2006\end{array}$ \\
\hline & $\begin{array}{l}\text { Institutional } \\
\text { and behavioral } \\
\text { economics }\end{array}$ & $\begin{array}{l}\text { Understand how formal and } \\
\text { informal institutions shape } \\
\text { stakeholder incentives and } \\
\text { conservation outcomes. } \\
\text { Understand contexts where } \\
\text { stakeholder behavior departs } \\
\text { from rationality assumptions }\end{array}$ & & & $\checkmark$ & $\begin{array}{l}\text { Aburto-Oropeza et al. 2018; } \\
\text { Li et al 2016; Stephenson et } \\
\text { al. 2017; Barnes-Mauthe et al. } \\
\text { 2015; Boisvert 2015; } \\
\text { Sawchuk et al. 2015; Ostrom } \\
\text { and Basurto 2011; Abbot and } \\
\text { Wilen } 2009\end{array}$ \\
\hline $\begin{array}{l}\text { Estimating } \\
\text { stakeholder } \\
\text { preferences and } \\
\text { values }\end{array}$ & $\begin{array}{l}\text { Nonmarket } \\
\text { valuation }\end{array}$ & $\begin{array}{l}\text { Evaluate stakeholder and public } \\
\text { preferences for conservation } \\
\text { policies and associated changes } \\
\text { in ecosystem services }\end{array}$ & $\checkmark$ & & $\checkmark$ & $\begin{array}{l}\text { Lewis et al. 2019; Dundas et } \\
\text { al. 2018; Wallmo and Lew } \\
\text { 2015; Pienaar et al. } 2017\end{array}$ \\
\hline \multirow{4}{*}{$\begin{array}{l}\text { Evaluating } \\
\text { alternative } \\
\text { courses of } \\
\text { action }\end{array}$} & $\begin{array}{l}\text { Reserve site } \\
\text { selection and } \\
\text { related spatial } \\
\text { prioritization } \\
\text { methods } \\
\text { (RSS)* }\end{array}$ & $\begin{array}{l}\text { Spatial prioritization of nature } \\
\text { preserves and other spatially } \\
\text { explicit conservation actions to } \\
\text { meet conservation objectives } \\
\text { (e.g., marine protected areas) }\end{array}$ & $\checkmark$ & $\checkmark$ & & $\begin{array}{l}\text { Newbold and Siikamäki } \\
\text { 2009; Sanchirico 2004; Leslie } \\
\text { et al. 2003; Polasky and } \\
\text { Solow } 2001\end{array}$ \\
\hline & $\begin{array}{l}\text { Cost } \\
\text { effectiveness } \\
\text { analysis (CEA) }\end{array}$ & \multirow{2}{*}{$\begin{array}{l}\text { Evaluate and prioritize } \\
\text { alternative recovery strategies } \\
\text { or } \\
\text { Evaluate and prioritize } \\
\text { alternatives to reduce scientific } \\
\text { uncertainty }\end{array}$} & $\checkmark$ & $\checkmark$ & & $\begin{array}{l}\text { Rose et al. 2016; Gjertsen et } \\
\text { al. } 2014\end{array}$ \\
\hline & $\begin{array}{l}\text { Cost benefit } \\
\text { analysis (CBA) }\end{array}$ & & $\checkmark$ & $\checkmark$ & & $\begin{array}{l}\text { Bisack and Magnusson 2014; } \\
\text { Sanchirico et al. 2013; DOI } \\
\text { 2012; }\end{array}$ \\
\hline & $\begin{array}{l}\text { Real options } \\
\text { analysis }\end{array}$ & $\begin{array}{l}\text { Optimal timing of conservation } \\
\text { interventions }\end{array}$ & $\checkmark$ & $\checkmark$ & & $\begin{array}{l}\text { Conrad 2018; Speir et al. } \\
2015\end{array}$ \\
\hline
\end{tabular}




\subsection{Developing policy instruments and understanding their effects}

MPR policy interventions can help produce socially desirable levels of conservation and related ecosystem services when markets fail to do so. This is often the case for marine ecosystems where challenges with establishing property rights can give rise to common pool resource problems and other sources of market failure. Designing policy instruments that promote conservation objectives is a difficult but essential task that involves assessing the current conditions and dynamic threats facing MPR, and proposing policy alternatives to address those threats.

Top-down policy instruments directly regulate stakeholder activities while market-based policy instruments incentivize stakeholders to make choices that align with conservation objectives. Restricting commercial fishing within a designated marine protected area, for instance, is a top-down instrument. On the other hand, market-based approaches include capand-trade systems that address common-pool resource problems through the establishment of property rights as well as carrot-and-stick approaches that reward socially desirable behavior and penalize undesirable behavior. The cap-and-trade approach is applicable to pollution control, commercial fisheries target catch (e.g., individual tradeable quotas) and bycatch (Lent and Squires, 2017), and tourism (Higham et al., 2016). The Chinook salmon bycatch reduction incentive plan in Alaska's Bering Sea and Aleutian Islands pollock fishery (CFR, 2016) is an example of a carrot-and-stick approach applied to MPR management. This policy incentivizes 
bycatch avoidance by restricting pollock fishing opportunities for vessels with poor bycatch performance while granting additional fishing opportunities to vessels with lower bycatch levels. Market-based instruments also include taxes that incentivize environmentally desirable behavior (e.g., a bycatch tax) and risk pools that provide a means for sharing the risk of unintended impacts on MPR across resource users (Holland and Jannot, 2012). Lent (2015) and others have advocated for market-based instruments to help address the major threats facing marine mammals. Further, empirical analyses have found that market mechanisms can foster efficient outcomes for MPR and associated stakeholders. For example, Bisack and Sutinen (2006) modeled fisher behavior in the New England gillnet fishery under alternative harbor porpoise bycatch reduction policies and found that management of bycatch with individual tradable quotas lead to higher fishing rents compared to management with area closures. For a review of using market-based instruments to mitigate undesirable ecosystem impacts, see Innes et al. (2015).

Developing policy instruments involves predicting how alternative policies will influence MPR outcomes of interest and associated stakeholders. Predicting these effects requires an understanding of how management actions interact with ecosystem processes and stakeholder preferences to shape stakeholder incentives and conservation outcomes over time. Bioeconomic models, or models of interacting biological and economic systems, are commonly employed in concert with dynamic analysis to analyze these effects in protected resources contexts. A common application of bioeconomic models to MPR management context is simulating the effects of management measures and evaluating different scenarios according to their ecological and socio-economic impacts (see Nielsen et al., 2018).

Sometimes recovery and conservation policies cause spillovers, or effects beyond the jurisdiction or intended focus of the policy. These effects can occur through a variety of 
channels, including input reallocation, prices, and ecological-physical linkages (see Pfaff and Robalino, 2017 for a review). In a MPR example, Chan and Pan (2016) found that fishery regulations designed to reduce sea turtle mortality by closing a US fishery once a bycatch limit had been reached led to a spillover effect of higher fishing effort by non-US vessels with little to no mitigation measures in place to avoid or reduce bycatch.

Strategic interactions arise when the best course of action for stakeholders depends on the behavior of other stakeholders. Game theory, or the mathematical analysis of strategic behavior between decision-makers, and other economic tools can help explain stakeholder incentives and predict strategic behavior in these situations (e.g., Abbott and Wilen, 2009). Another important type of stakeholder behavior is compliance with regulations, and economic tools can examine compliance decisions and associated stakeholder incentives (e.g., Bisack and Das, 2015; Langpap and $\mathrm{Wu}, 2017)$

In addition to evaluating candidate recovery policies prospectively, researchers also study the effects of past policies on conservation outcomes with tools designed to infer causal relationships. Random controlled trials (RCT) are the ideal tool for determining causality, but are often infeasible or unethical in the MPR context. Other tools include instrumental variables, difference-in-differences, synthetic controls, regression discontinuity designs, and traditional potential outcome approaches (see Athey and Imbens, 2017 for a recent review).

Causal inference in the context of MPR is challenging. Ferraro et al. (2019) used marine reserves as an example to discuss and illustrate the challenges of applying causal inference methods in the context of coupled human and natural systems. Sills and Jones (2018) reviewed methods and evidence related to causal inference in environmental conservation, with an emphasis on institutional considerations. 
Finally, institutional analysis is a tool that informs how formal or informal institutional arrangements can address common-pool resource problems and other market failures related to MPR management. Institutions can play an important role in MPR management and recovery outcomes. The field of institutional economics has developed a vast literature focused on understanding how institutions shape economic behavior (Coase, 1937; Commons, 1934; North, 1991; Williamson, 1979). Elinor Ostrom's influential theory on the governance of common-pool resources describes how rules, operating at multiple social organization levels, influence the outcome achieved by individual users of natural resources (Ostrom, 1990). This paved the way for important contributions of economic analysis for understanding how MPR institutions shape stakeholder behavior and conservation outcomes. Hanna (2008) evaluated institutional requirements for managing healthy and resilient salmonid ecosystems with an emphasis on the role of stakeholder incentives and transaction costs. Ostrom and Basurto (2011) developed tools for evaluating alternative institutional arrangements and Stephenson et al. (2017) offered guidance for integrating institutional and economic considerations into fisheries policy. Li et al. (2016) used institutional analysis to develop a governance framework for considering ecosystem services in coastal and marine natural resource management. Boisvert (2015) used institutional analysis to describe the characteristics of conservation banking mechanisms and showed that these arrangements are essentially limited to localized transactions without transfer of property rights, and thus should not be considered as market-based instruments.

In addition to formal institutions, stakeholder engagement, education, and involvement are increasingly recognized as important institutional considerations for protected resources management (e.g., Aburto-Oropeza et al., 2018; Duvall et al., 2017; Sawchuk et al., 2015). The development of social norms (Ostrom, 2002) and the influence of social capital (e.g., Barnes- 
Mauthe et al., 2015) on environmental outcomes are other informal institutions of interest to economists and other social scientists.

Transaction costs (Coase, 1937) are another institutional consideration when attempting to identify effective forms of regulation. Transaction costs are the resources needed to define, establish, use and change institutions, and to define the problems these institutions are designed to solve (Marshall, 2013). Empirical research almost never seeks to directly measure these costs. Rather, they attempt to demonstrate the existence of an inequality between the transaction costs associated with different institutional arrangements (Masten and Saussier, 2000). For example, Kuperan et al. (2008) compared the transaction costs associated with different fisheries resources management options and found that co-management systems economize on the cost of monitoring and enforcement as compared to centralized government management systems.

\subsection{Estimating stakeholder preferences and values}

Protected resources stakeholders, including the public, have preferences over MPR policy instruments and their effects. Estimating these preferences, and changes in welfare associated with the effects, helps managers weigh the costs and benefits of candidate interventions. Nonmarket valuation is an economic tecnique to estimate stakeholder preferences over alternative conservation outcomes, and their willingness to pay for obtaining or avoiding those outcomes. The economic costs and benefits of some recovery policies, for example, foregoing hydropower production to protect species in river systems, are revealed directly through observed market prices. However, the values associated with species recovery and conservation are typically not revealed in markets.

Stated preference (SP) and revealed preference (RP) nonmarket valuation methods are tools used to estimate the economic value of goods whose values are not revealed in markets. Stated 
preference studies employ survey techniques to elicit preferences over alternative conservation policies and willingness to pay for related nonmarket values (e.g., ecosystem services values). Two common SP methods are contingent valuation and choice experiments. Contingent valuation questions carefully describe a stylized market to elicit information on the maximum a respondent is willing to pay (or accept) to obtain a good or service (Boyle, 2012). For example, Bell et al. (2003) asked residents of coastal communities how they would vote on a hypothetical ballot measure whose effects would increase the allowable catch of endangered salmon at a specified dollar cost to local households. Choice experiments for valuing environmental goods present respondents with decisions among alternative environmental outcomes that systematically vary according to specified attributes, including their cost to respondents. Compared to contingent valuation, choice experiments facilitate valuation of individual characteristics of non-market environmental goods. For example, a recent study by Lewis et al. (2019) employed a choice experiment to estimate the non-market benefits of undertaking conservation investments to help recovery of Pacific Coho salmon on the Oregon coast in the US. Lew (2015) provides a detailed review of past SP studies that measure willingness to pay for MPR recovery and conservation.

RP methods value ecosystem services through behavioral observations under utility maximization assumptions. Travel cost models use data on trip-taking behavior and distance traveled to given sites, often recreation sites, to estimate demand for recreation resources. Dundas et al. (2018) used the travel cost method to value the costs of recreational off-road vehicle closures for endangered species protection at a National Seashore. Hedonic pricing models decompose the sales prices of real estate transactions and other differentiated goods by their attributes (e.g., lot size, square footage, proximity to parkland), which include 
environmental amenities. In one application to MPR management, Netusil and Summers (2009) used hedonic pricing to decompose payments for instream flows according to the relevant attributes, including whether the stream included ESA-listed species.

Ecological production functions are a valuation method that models ecosystems as factors of production for valuable goods and services--for example the value coastal ecosystems provide by serving as inputs for various ecosystem services. For example, Cole and Moksnes (2016) employ an ecological production function approach to value eelgrass based on its role in sustaining commercial fisheries and other ecosystem services.

Appropriate valuation of nonmarket goods and services requires significant expertise and financial resources. When estimation of these values is not feasible, rigorous application of benefit transfer (BT) methods can also inform recovery policy evaluation. Benefit transfer involves applying values derived from a given study site to a different policy site. Past

applications include valuation of specie recovery (Loomis and White, 1996; Weber, 2015) and other ecosystem services (Richardson et al., 2015).

Estimates of ecosystem service values and stakeholder preferences can inform the development and evaluation of MPR management policies. Cost-benefit analysis, which is discussed in a subsequent section, can involve estimation of nonmarket benefits and costs with the tools discussed above. Likewise, stakeholder preference parameters and welfare measures can serve as inputs to evaluation criteria for recovery action evaluation (e.g., Sanchirico et al., 2013)

\subsection{Evaluating alternative policy instruments and research efforts}

Upon having defined candidate conservation actions in terms of policy instruments and research efforts, and having considered the effects of the alternatives on human and natural systems, a 
remaining step is to evaluate and prioritize the candidate actions. Cost-effectiveness analysis (CEA) and cost-benefit analysis (CBA) are two widely used frameworks for evaluating candidate policies and actions. CBA evaluates alternatives based on their net present benefits, or total benefits less total costs, and typically involves estimation of the monetary costs and benefits associated with alternatives. Because CBA considers all project benefits and costs, including opportunity costs, economic theory suggests that all projects with net present benefits greater than one are socially efficient. As an example of the former, the US Department of the Interior and partners completed a CBA to evaluate the costs and benefits of removing four hydroelectric dams on the Klamath River in California, in part to improve habitat for imperiled wild salmonid populations (DOI, 2012).

On the other hand, CEA identifies least-cost alternatives for achieving a specified objective (e.g., achieving recovery goal), or alternatively identifies alternatives that yield the most progress towards conservation objectives subject to a budget constraint. In species recovery contexts, meaningfully applying CEA requires an understanding of how candidate recovery actions influence recovery progress and the costs of candidate actions. Compared to CBA, a key advantage of CEA is that it allows for costs and benefits to be measured in different units, and thus does not require estimation of the monetary benefits recovery actions. In one application of CEA to MPR management, Gjertsen et al. (2014) used a population model and cost data in Monte Carlo simulations to conduct a stochastic CEA of alternative conservation strategies for leatherback turtles.

Reserve site selection (RSS) methods involve spatial prioritization of conservation activities to maximize conservation benefits subject to a budget constraint. Ando and Langpap (2018) provide a review of the techniques and findings in the RSS literature as they relate to endangered 
species management. One key finding is that incorporating costs is often critical to the performance of RSS methods (e.g., Ando et al., 1998; Ferraro, 2003). In the MPR context, RSS methods have been applied to the development of marine reserves (Leslie et al., 2003; Sanchirico, 2004) and to manage lands use to improve habitat for endangered salmon (Newbold and Siikamäki, 2009).

The field of conservation return on investment analysis refers to use of CEA, CBA, RSS, bioeconomic modeling, and other methods for evaluating the costs, benefits, and risks of conservation alternatives, typically in the context of investing scarce conservation resources (Boyd et al., 2015).

Economic impacts, distributional effects, and environmental justice are additional factors to consider in addition to economic costs and benefits. Economic impact analyses examine the effect of conservation alternatives on business revenue, wages, and employment in a specified community or area. Distributional effects refer to how the costs and benefits of policies are distributed across the affected population. These effects are important to consider in the context of species recovery, where the benefits are likely to be geographically widespread but the costs may be concentrated in a certain community or region (Boxall et al., 2012; Mansfield et al., 2012; Sanchirico et al., 2013).

The timing of recovery costs and benefits is an important consideration in evaluating policy alternatives. In general, stakeholders prefer current benefits to future benefits and prefer incurring costs in the future to incurring costs now. In the case of Pacific salmon, for example, Lewis et al. (2019) found that the public placed significant value on achieving species recovery more quickly. These time preferences are typically incorporated into CEA and CBA through the discounting of future values, though in practice determining an appropriate discount rate is 
challenging (e.g., Berman and Sumaila, 2006; Sumaila and Walters, 2005; Weitzman, 2001). The optimal timing of conservation policies can be evaluated with net present value approaches, or with real options approaches that explicitly incorporate project uncertainty and the ability to modify conservation interventions as uncertain outcomes are realized. Conrad (2018) argued that endangered species are a quasi-public good and developed a model for determining the optimal timing of conservation interventions for endangered species using real options theory. Likewise, Speir et al. (2015) considered the optimal timing of dam removal to protect endangered salmonids in California. The authors found that uncertainty in ecosystem costs creates public incentives to delay implementation while irreversibility effects such as extinction create incentives to hasten implementation.

Besides serving as a framework to prioritize policy alternatives, economic tools can help address scientific uncertainty. For example, CEA can help inform data collection and monitoring effort allocation decisions when these activities are undertaken for the purpose of increasing the predictive power or parameter precision of a statistical model. Estimating and analyzing the value of the scientific information is another tool for addressing uncertainty with economic analysis. The value of scientific information can include the value of reduced extinction risk associated with improved decision-making or the value to stakeholders of relaxing use regulations. Likewise, CBA can inform evaluation of candidate research efforts based on the economic value of the scientific information that is expected to be obtained from those allocations. For example, increasing the precision of marine mammal population estimates (i.e., reducing uncertainty) could allow for a reduction of the regulatory burden on fishers. Bisack and Magnusson (2014) examined the economic value of increased precision in marine mammal stock estimates and found that the benefits to private industry from increased precision more than 
offset the costs of the data collection. In another application related to uncertainty, Tomberlin (2010) addressed the question of whether to undertake costly biological monitoring or allow human use when it is not known whether a species is present in a given habitat area. The study provides an example of using dynamic economic analysis to operationalize adaptive management when learning is possible.

\section{Conclusions}

This article assessed opportunities for informing MPR management with economic analysis. Through a review of the published literature and exploration of relevant management contexts, we assessed the current role economics plays in MPR management in several countries and identified three key challenges facing MPR managers. The three management challenges identified were getting the most out of scarce conservation resources, considering scientific uncertainty in management and research decisions, and fostering effective MPR institutions and governance. Further, we identified types of economic analysis that can help address these challenges. Examples of prior applications of economic analysis to MPR were also identified and discussed for context.

Several takeaways emerged from our review. First, the review highlighted that in the Anthropocene, the resources available for MPR recovery actions, data collection, and research are insufficient compared to what is necessary to recover all imperiled species and resources. Economic analysis provides useful tools for weighing tradeoffs associated with allocation of recovery resources and research efforts, and for assessing the social benefits of conservation activities. Second, our review revealed that while economic analysis plays a limited role in policies governing MPR management in the USA, Canada, and Europe, momentum for 
economic analysis may be building. This is reflected in research that recognizes that MPR management involves resource allocation decisions (Gerber et al., 2018; Joseph et al., 2009), and that incorporation of economic considerations into conservation decision-making can improve recovery outcomes (Murdoch et al., 2007; Underwood et al., 2009; Wilson et al., 2006). Moreover, there is also increased attention to the institutional drivers of MPR management success, and strategies for fostering durable and effective MPR governance (Burgess et al., 2016; Stephenson et al., 2017).

We note that this review is not exhaustive in its coverage of economic tools and literature. The economic tools and related empirical applications covered in this review were selected based on their relevance to identified management challenges. Thus, the review was not comprehensive in terms of coverage and should not be viewed as such. Likewise, the review did not cover all challenges facing MPR managers, instead focusing on three pressing challenges.

Moving forward, fostering the use of economic analysis to inform MPR management will require improved communication regarding the tools and frameworks available, and guidance regarding their appropriate application. As highlighted in this review, the scope of economic analysis goes beyond identifying conservation approaches that allocate available resources costeffectively. It also encompasses estimating, and incorporating into decision making, the nonmarket benefits of MPR conservation and understanding the institutional drivers of management outcomes. Communicating these functions to resource managers and framing economic analysis as a means of advancing conservation goals, rather than a means of highlighting potential inefficiencies, may further facilitate its application and usefulness management. 
Integrating economic analysis into ecosystem-based management, an increasingly prevalent conservation approach, will also help facilitate its use and effectiveness. Ecosystem-based management (EBM) approaches consider all ecosystem components (e.g., habitats, protected and non-protected species, fisheries and other maritime sectors) and their interactions (Levin et al., 2009; McLeod and Leslie, 2009). Our review identified some relevant economic tools to address multi-objective management (e.g., bioeconomic modeling) and governance conflicts (e.g., institutional analysis). Yet integrated assessments of MPR policy alternatives remain limited and more research is needed to fill this gap, including the development of cross-sectoral approaches that consider trade offs across species, jurisdictions and, user groups (Lester et al., 2013; Levin and Möllmann, 2015; White et al., 2012).

Finally, shifting baselines are an important consideration when applying economic analysis to MPR management. In particular, planning effective MPR conservation policies involves consideration of ongoing changes in environmental, social, and economic conditions. Accounting for these shifting baselines is critical for crafting effective conservation strategies (Papworth et al., 2009; Pauly, 1995).

\section{References}

Abbott, J.K., Wilen, J.E., 2009. Regulation of fisheries bycatch with common-pool output quotas. Journal of Environmental Economics and Management 57, 195-204. Aburto-Oropeza, O., López-Sagástegui, C., Moreno-Báez, M., Mascareñas-Osorio, I., JiménezEsquivel, V., Johnson, A.F., Erisman, B., 2018. Endangered species, ecosystem integrity, and human livelihoods. Conservation Letters 11, e12358. 
Adamowicz, W.L.V., 2016. Economic Analysis and Species at Risk: Lessons Learned and Future Challenges. Canadian Journal of Agricultural Economics/Revue canadienne d'agroeconomie $64,21-32$.

Ando, A., Camm, J., Polasky, S., Solow, A., 1998. Species distributions, land values, and efficient conservation. Science 279, 2126-2128.

Ando, A.W., Langpap, C., 2018. The Economics of Species Conservation. Annual Review of Resource Economics.

Athey, S., Imbens, G.W., 2017. The state of applied econometrics: Causality and policy evaluation. Journal of Economic Perspectives 31, 3-32.

Balmford, A., Gaston, K.J., Blyth, S., James, A., Kapos, V., 2003. Global variation in terrestrial conservation costs, conservation benefits, and unmet conservation needs. Proceedings of the National Academy of Sciences 100, 1046-1050.

Barnes-Mauthe, M., Gray, S.A., Arita, S., Lynham, J., Leung, P., 2015. What determines social capital in a social-ecological system? Insights from a network perspective. Environmental management 55, 392-410.

Bayraktarov, E., Saunders, M.I., Abdullah, S., Mills, M., Beher, J., Possingham, H.P., Mumby, P.J., Lovelock, C.E., 2016. The cost and feasibility of marine coastal restoration. Ecological Applications 26, 1055-1074.

Bell, K.P., Huppert, D., Johnson, R.L., 2003. Willingness to pay for local coho salmon enhancement in coastal communities. Marine Resource Economics 18, 15-31.

Berman, M., Sumaila, U.R., 2006. Discounting, amenity values, and marine ecosystem restoration. Marine Resource Economics 21, 211-219. 
Bisack, K.D., Das, C., 2015. Understanding non-compliance with protected species regulations in the northeast USA gillnet fishery. Frontiers in Marine Science 2, 91.

Bisack, K.D., Magnusson, G., 2014. Measuring the economic value of increased precision in scientific estimates of marine mammal abundance and bycatch: Harbor porpoise Phocoena phocoena in the northeast US gill-net fishery. North American journal of fisheries management 34, 311-321.

Bisack, K.D., Sutinen, J.G., 2006. Harbor porpoise bycatch: ITQs or time/area closures in the New England gillnet fishery. Land Economics 82, 85-102.

Boisvert, V., 2015. Conservation banking mechanisms and the economization of nature: An institutional analysis. Ecosystem Services 15, 134-142.

Boxall, P., Adamowicz, W., Olar, M., West, G., Cantin, G., 2012. Analysis of the economic benefits associated with the recovery of threatened marine mammal species in the Canadian St. Lawrence Estuary. Marine Policy 36, 189-197.

Boyd, J., Epanchin-Niell, R., Siikamäki, J., 2015. Conservation planning: a review of return on investment analysis. Review of Environmental Economics and Policy 9, 23-42.

Boyle, K.J., 2012. Contingent Valuation in Practice, A Primer on Nonmarket Valuation, pp. 111169.

Brazill-Boast, J., Williams, M., Rickwood, B., Partridge, T., Bywater, G., Cumbo, B., Shannon, I., Probert, W.J., Ravallion, J., Possingham, H., 2018. A large-scale application of project prioritization to threatened species investment by a government agency. PloS one 13, e0201413. 
Brechin, S.R., Wilshusen, P.R., Fortwangler, C.L., West, P.C., 2002. Beyond the square wheel: toward a more comprehensive understanding of biodiversity conservation as social and political process. Society \&Natural Resources 15, 41-64.

Brown, C.J., Bode, M., Venter, O., Barnes, M.D., McGowan, J., Runge, C.A., Watson, J.E., Possingham, H.P., 2015. Effective conservation requires clear objectives and prioritizing actions, not places or species. Proceedings of the National Academy of Sciences 112, E4342E4342.

Burgess, M.G., Clemence, M., McDermott, G.R., Costello, C., Gaines, S.D., 2016. Five rules for pragmatic blue growth. Marine Policy.

CFR, 2016. Fisheries of the Exclusive Economic Zone Off Alaska; Bycatch Management in the Bering Sea Pollock Fishery, in: NOAA (Ed.).

Chan, H.L., Pan, M., 2016. Spillover effects of environmental regulation for sea turtle protection in the Hawaii longline swordfish fishery. Marine Resource Economics 31, 259-279.

Coase, R.H., 1937. The nature of the firm. economica 4, 386-405.

Cole, S.G., Moksnes, P.-O., 2016. Valuing multiple eelgrass ecosystem services in Sweden: fish production and uptake of carbon and nitrogen. Frontiers in Marine Science 2, 121.

Commons, J.R., 1934. Institutional Economics: Its Place in Political Economy. Macmillan Company, New, York.

Conrad, J.M., 2018. Real Options for Endangered Species. Ecological Economics 144, 59-64.

Conrad, J.M., Rondeau, D., 2015. Bioeconomics of a marine disease. Marine Resource Economics 30, 393-416.

Costello, C., Polasky, S., Solow, A., 2001. Renewable resource management with environmental prediction. Canadian Journal of Economics 34, 196-211. 
Costello, C.J., Adams, R.M., Polasky, S., 1998. The value of El Niño forecasts in the management of salmon: a stochastic dynamic assessment. American Journal of Agricultural Economics 80, 765-777.

Crowder, L.B., Osherenko, G., Young, O.R., Airamé, S., Norse, E.A., Baron, N., Day, J.C., Douvere, F., Ehler, C.N., Halpern, B.S., 2006. Resolving mismatches in US ocean governance. Science 313, 617-618.

Di Marco, M., Chapman, S., Althor, G., Kearney, S., Besancon, C., Butt, N., Maina, J.M., Possingham, H.P., von Bieberstein, K.R., Venter, O., 2017. Changing trends and persisting biases in three decades of conservation science. Global Ecology and Conservation 10, 32-42.

Dietz, T., Ostrom, E., Stern, P.C., 2003. The struggle to govern the commons. science 302, 19071912.

DOI, 2012. Klamath Dam Removal Overview Report For the Secretary of Interior: An Assessment of Science and Technical Information. U.S. Department of Interior; U.S. Department of Commerce, National Marine Fisheries Service.

Duke, J.M., Dundas, S.J., Messer, K.D., 2013. Cost-effective conservation planning: lessons from economics. Journal of environmental management 125, 126-133.

Dundas, S.J., von Haefen, R.H., Mansfield, C., 2018. Recreation Costs of Endangered Species Protection: Evidence from Cape Hatteras National Seashore. Marine Resource Economics $33,1-25$.

Duvall, A.L., Metcalf, A.L., Coates, P.S., 2017. Conserving the greater sage-grouse: a socialecological systems case study from the California-Nevada region. Rangeland Ecology and Management 70, 129-140. 
Essington, T.E., Sanchirico, J.N., Baskett, M.L., 2018. Economic value of ecological information in ecosystem-based natural resource management depends on exploitation history.

Proceedings of the National Academy of Sciences 115, 1658-1663.

EU-Commission, 2011. Guidelines on the Implementation of the Birds and Habitats Directives in Esturaries and Coastal Zones, in: Environment (Ed.).

Ferraro, P.J., 2003. Assigning priority to environmental policy interventions in a heterogeneous world. Journal of Policy Analysis and Management 22, 27-43.

Ferraro, P.J., Sanchirico, J.N., Smith, M.D., 2019. Causal inference in coupled human and natural systems. Proceedings of the National Academy of Sciences 116, 5311-5318.

Gerber, L.R., 2016. Conservation triage or injurious neglect in endangered species recovery. Proceedings of the National Academy of Sciences 113, 3563-3566.

Gerber, L.R., Runge, M.C., Maloney, R.F., Iacona, G.D., Drew, C.A., Avery-Gomm, S., BrazillBoast, J., Crouse, D., Epanchin-Niell, R.S., Hall, S.B., 2018. Endangered species recovery: A resource allocation problem. Science 362, 284-286.

Gjertsen, H., Squires, D., Dutton, P.H., Eguchi, T., 2014. Cost-Effectiveness of Alternative Conservation Strategies with Application to the Pacific Leatherback Turtle. Conservation biology 28, 140-149.

Gopalakrishnan, C., 2005. Water allocation and management in Hawaii: A case of institutional entropy, Water institutions: Policies, performance and prospects. Springer, pp. 1-23.

Halpern, B.S., Walbridge, S., Selkoe, K.A., Kappel, C.V., Micheli, F., D'agrosa, C., Bruno, J.F., Casey, K.S., Ebert, C., Fox, H.E., 2008. A global map of human impact on marine ecosystems. Science 319, 948-952. 
Hanna, S., 2008. Institutions for managing resilient salmon (Oncorhynchus spp.) ecosystems: the role of incentives and transaction costs. Ecology and Society 13.

Higham, J.E., Bejder, L., Allen, S.J., Corkeron, P.J., Lusseau, D., 2016. Managing whalewatching as a non-lethal consumptive activity. Journal of Sustainable Tourism 24, 73-90.

Holland, D.S., Jannot, J.E., 2012. Bycatch risk pools for the US West coast groundfish fishery. Ecological Economics 78, 132-147.

Huang, B., Langpap, C., Adams, R.M., 2012. The value of in-stream water temperature forecasts for fisheries management. Contemporary Economic Policy 30, 247-261.

Hutniczak, B., Lipton, D., Wiedenmann, J., Wilberg, M.J., 2018. Valuing Changes in Frequency of Fish Stock Assessments. Canadian Journal of Fisheries and Aquatic Sciences.

Innes, J., Pascoe, S., Wilcox, C., Jennings, S., Paredes, S., 2015. Mitigating undesirable impacts in the marine environment: a review of market-based management measures. Frontiers in Marine Science 2, 76.

Ives, C.D., Kendal, D., 2014. The role of social values in the management of ecological systems. Journal of environmental management 144, 67-72.

Joseph, L.N., Maloney, R.F., O’connor, S.M., Cromarty, P., Jansen, P., Stephens, T., Possingham, H.P., 2008. Improving methods for allocating resources among threatened species: the case for a new national approach in New Zealand. Pacific Conservation Biology $14,154-158$.

Joseph, L.N., Maloney, R.F., Possingham, H.P., 2009. Optimal allocation of resources among threatened species: a project prioritization protocol. Conservation biology 23, 328-338.

Kuperan, K., Abdullah, N.M.R., Pomeroy, R.S., Genio, E., Salamanca, A., 2008. Measuring transaction costs of fisheries co-management. Coastal Management 36, 225-240. 
Langpap, C., Kerkvliet, J., Shogren, J.F., 2018. The Economics of the U.S. Endangered Species Act: A Review of Recent Developments. Review of Environmental Economics and Policy $12,69-91$.

Langpap, C., Wu, J., 2017. Thresholds, Perverse Incentives, and Preemptive Conservation of Endangered Species. Journal of the Association of Environmental and Resource Economists 4, S227-S259.

LaRiviere, J., Kling, D., Sanchirico, J.N., Sims, C., Springborn, M., 2017. The Treatment of Uncertainty and Learning in the Economics of Natural Resource and Environmental Management. Review of Environmental Economics and Policy.

Lent, R., Squires, D., 2017. Reducing marine mammal bycatch in global fisheries: An economics approach. Deep Sea Research Part II: Topical Studies in Oceanography 140, 268-277.

Lent, R.J., 2015. Conservation benefits of an interdisciplinary approach to marine mammal science. Frontiers in Marine Science 2, 67.

Leslie, H., Ruckelshaus, M., Ball, I.R., Andelman, S., Possingham, H.P., 2003. Using siting algorithms in the design of marine reserve networks. Ecological applications 13, 185-198.

Lester, S.E., Costello, C., Halpern, B.S., Gaines, S.D., White, C., Barth, J.A., 2013. Evaluating tradeoffs among ecosystem services to inform marine spatial planning. Marine Policy 38, 8089.

Levin, P.S., Fogarty, M.J., Murawski, S.A., Fluharty, D., 2009. Integrated ecosystem assessments: developing the scientific basis for ecosystem-based management of the ocean. PLoS biology 7, e1000014. 
Levin, P.S., Möllmann, C., 2015. Marine ecosystem regime shifts: challenges and opportunities for ecosystem-based management. Philosophical Transactions of the Royal Society of London B: Biological Sciences 370, 20130275.

Lew, D.K., 2015. Willingness to pay for threatened and endangered marine species: a review of the literature and prospects for policy use. Frontiers in Marine Science 2, 96.

Lewis, D.J., Dundas, S.J., Kling, D.M., Lew, D.K., Hacker, S.D., 2019. The non-market benefits of early and partial gains in managing threatened salmon. PloS one 14, e0220260.

Li, R., van den Brink, M., Woltjer, J., 2016. Rules for the governance of coastal and marine ecosystem services: An evaluative framework based on the IAD framework. Land Use Policy 59, 298-309.

Libecap, G.D., 2014. Addressing global environmental externalities: Transaction costs considerations. Journal of Economic Literature 52, 424-479.

Long, R.D., Charles, A., Stephenson, R.L., 2015. Key principles of marine ecosystem-based management. Marine Policy 57, 53-60.

Loomis, J.B., White, D.S., 1996. Economic benefits of rare and endangered species: summary and meta-analysis. Ecological Economics 18, 197-206.

Macintosh, A., Wilkinson, D., 2005. Environment Protection and Biodiversity Conservation Act: A Five Year Assessment. Australia Institute.

Malcom, J.W., Li, Y.W., 2018. Missing, delayed, and old: The status of ESA recovery plans. Conservation Letters 11, e12601.

Mansfield, C., Van Houtven, G., Hendershott, A., Chen, P., Porter, J., Nourani, V., Kilambi, V., 2012. Klamath River basin restoration nonuse value survey. US Bureau of Reclamation. RTI Project, 010 . 
Marshall, G.R., 2013. Transaction costs, collective action and adaptation in managing complex social-ecological systems. Ecological Economics 88, 185-194.

Masten, S., Saussier, S., 2000. Econometrics of contracts: an assessment of developments in the empirical literature on contracting. Revue d'économie industrielle 92, 215-236.

McCarthy, D.P., Donald, P.F., Scharlemann, J.P., Buchanan, G.M., Balmford, A., Green, J.M., Bennun, L.A., Burgess, N.D., Fishpool, L.D., Garnett, S.T., 2012. Financial costs of meeting global biodiversity conservation targets: current spending and unmet needs. Science 338, 946-949.

McCauley, D.J., Pinsky, M.L., Palumbi, S.R., Estes, J.A., Joyce, F.H., Warner, R.R., 2015. Marine defaunation: animal loss in the global ocean. Science 347, 1255641.

McDevitt-Irwin, J.M., Fuller, S.D., Grant, C., Baum, J.K., 2015. Missing the safety net: evidence for inconsistent and insufficient management of at-risk marine fishes in Canada. Canadian Journal of Fisheries and Aquatic Sciences 72, 1596-1608.

McLeod, K., Leslie, H., 2009. Why Ecosystem-Based Management, Second ed. Island Press, Washington, DC.

McLeod, K.L., Lubchenco, J., Palumbi, S.R., Rosenberg, A.A., 2005. Scientific consensus statement on marine ecosystem-based management. Signed by 221, 1-21.

Metrick, A., Weitzman, M.L., 1996. Patterns of behavior in endangered species preservation. Land Economics, 1-16.

Mooers, A.O., Doak, D.F., Scott Findlay, C., Green, D.M., Grouios, C., Manne, L.L., Rashvand, A., Rudd, M.A., Whitton, J., 2010. Science, policy, and species at risk in Canada. BioScience 60, 843-849. 
Murdoch, W., Polasky, S., Wilson, K.A., Possingham, H.P., Kareiva, P., Shaw, R., 2007. Maximizing return on investment in conservation. Biological Conservation 139, 375-388.

Netusil, N.R., Summers, M.T., 2009. Valuing instream flows using the hedonic price method. Water resources research 45 .

Newbold, S.C., Siikamäki, J., 2009. Prioritizing conservation activities using reserve site selection methods and population viability analysis. Ecological Applications 19, 1774-1790.

Nielsen, J.R., Thunberg, E., Holland, D.S., Schmidt, J.O., Fulton, E.A., Bastardie, F., Punt, A.E., Allen, I., Bartelings, H., Bertignac, M., 2018. Integrated ecological-economic fisheries models - Evaluation, review and challenges for implementation. Fish and Fisheries 19, 1-29.

NMFS, 2014. Proceedings of the 2014 NOAA Economics of Protected Resources Workshop, in: Service, N.M.F. (Ed.), La Jolla, California.

North, D.C., 1991. Institutions. Journal of economic perspectives 5, 97-112.

Ostrom, E., 1990. Governing the commons: the evolution of institutions for collective action. Cambridge University Press, Cambridge, UK.

Ostrom, E., 2002. Common-pool resources and institutions: toward a revised theory. Handbook of agricultural economics 2, 1315-1339.

Ostrom, E., Basurto, X., 2011. Crafting analytical tools to study institutional change. Journal of institutional economics 7, 317-343.

Papworth, S.K., Rist, J., Coad, L., Milner-Gulland, E.J., 2009. Evidence for shifting baseline syndrome in conservation. Conservation letters 2, 93-100.

Pauly, D., 1995. Anecdotes and the shifting baseline syndrome of fisheries. Trends in ecology \& evolution 10, 430 . 
Pfaff, A., Robalino, J., 2017. Spillovers from Conservation Programs. Annual Review of Resource Economics 9, 299-315.

Pikitch, E., Santora, C., Babcock, E., Bakun, A., Bonfil, R., Conover, D., Dayton, P., et al., Doukakis, P., Fluharty, D., Heneman, B., 2004. Ecosystem-based fishery management. American Association for the Advancement of Science.

Pimm, S.L., 2000. Against triage. American Association for the Advancement of Science, pp. 2289-2289.

Plantinga, A.J., Helvoigt, T.L., Walker, K., 2014. Critical habitat for threatened and endangered species: How should the economic costs be evaluated? Journal of environmental management 134, 127-135.

Polasky, S., Solow, A.R., 2001. The value of information in reserve site selection. Biodiversity \& Conservation 10, 1051-1058.

Richardson, L., Loomis, J., Kroeger, T., Casey, F., 2015. The role of benefit transfer in ecosystem service valuation. Ecological Economics 115, 51-58.

Ruckelshaus, M., Klinger, T., Knowlton, N., DeMaster, D.P., 2008. Marine ecosystem-based management in practice: scientific and governance challenges. AIBS Bulletin 58, 53-63.

Sanchirico, J.N., 2004. Designing a cost-effective marine reserve network: a bioeconomic metapopulation analysis. Marine Resource Economics 19, 41-65.

Sanchirico, J.N., Lew, D.K., Haynie, A.C., Kling, D.M., Layton, D.F., 2013. Conservation values in marine ecosystem-based management. Marine Policy 38, 523-530.

Sanchirico, J.N., Malvadkar, U., Hastings, A., Wilen, J.E., 2006. When are no-take zones an economically optimal fishery management strategy? Ecological Applications 16, 1643-1659. 
Sawchuk, J.H., Beaudreau, A.H., Tonnes, D., Fluharty, D., 2015. Using stakeholder engagement to inform endangered species management and improve conservation. Marine Policy 54, 98107.

Schultz, J.A., Darling, E.S., Côté, I.M., 2013. What is an endangered species worth? Threshold costs for protecting imperilled fishes in Canada. Marine Policy 42, 125-132.

Seabrook-Davison, M.N., Brunton, D.H., Ji, W., 2009. Future direction for the conservation of New Zealand? s biodiversity. Pacific Conservation Biology 15, 153-157.

Service, C.R., 2019. Final Rules Changing Endangered Species Act Regulations.

Sills, E.O., Jones, K., 2018. Causal inference in environmental conservation: the role of institutions, Handbook of environmental economics. Elsevier, pp. 395-437.

Speir, C., Pittman, S., Tomberlin, D., 2015. Uncertainty, Irreversibility and the Optimal Timing of Large-Scale Investments in Protected Species Habitat Restoration. Frontiers in Marine Science 2, 101.

Stephenson, R.L., Benson, A.J., Brooks, K., Charles, A., Degnbol, P., Dichmont, C.M., Kraan, M., Pascoe, S., Paul, S.D., Rindorf, A., 2017. Practical steps toward integrating economic, social and institutional elements in fisheries policy and management. ICES Journal of Marine Science 74, 1981-1989.

Sumaila, U.R., Walters, C., 2005. Intergenerational discounting: a new intuitive approach. Ecological Economics 52, 135-142.

Tomberlin, D., 2010. Endangered seabird habitat management as a partially observable Markov decision process. Marine Resource Economics 25, 93-104.

TSSC, 2017. Guidelines for nominating and assessing the eligibility for listing of ecological communities as threatened according to the Environment Protection and Biodiversity 
Conservation Act 1999 and the EPBC Regulations 2000, in: Threatened Species Scientific Committee, A.D.o.t.E.a.E. (Ed.).

Underwood, E.C., Klausmeyer, K.R., Morrison, S.A., Bode, M., Shaw, M.R., 2009. Evaluating conservation spending for species return: A retrospective analysis in California. Conservation Letters 2, 130-137.

USFWS, 2019a. ECOS Environmental Conservation Online System, U.S. Federal Endangered and Threatened Species by Calendar Year.

USFWS, 2019b. Environmental Conservation Online System, Delisted Species.

USFWS, 2019c. Environmental Conservation Online System, Generate Species Count.

Vatn, A., 2005. Rationality, institutions and environmental policy. Ecological Economics 55, 203-217.

Wallmo, K., Bisack, K.D., Lew, D.K., Squires, D.E., 2016. The Economics of Protected Marine Species: Concepts in Research and Management. Frontiers in Marine Science 3, 183.

Walsh, J.C., Watson, J.E., Bottrill, M.C., Joseph, L.N., Possingham, H.P., 2013. Trends and biases in the listing and recovery planning for threatened species: an Australian case study. Oryx 47, 134-143.

Waples, R.S., Nammack, M., Cochrane, J.F., Hutchings, J.A., 2013. A tale of two acts: endangered species listing practices in Canada and the United States. Bioscience 63, 723734.

Weber, M.A., 2015. Navigating benefit transfer for salmon improvements in the western US. Frontiers in Marine Science 2, 74.

Weitzman, M.L., 1998. The Noah's ark problem. Econometrica, 1279-1298.

Weitzman, M.L., 2001. Gamma discounting. American Economic Review 91, 260-271. 
White, C., Halpern, B.S., Kappel, C.V., 2012. Ecosystem service tradeoff analysis reveals the value of marine spatial planning for multiple ocean uses. Proceedings of the National Academy of Sciences, 201114215.

Williamson, O.E., 1979. Transaction-cost economics: the governance of contractual relations. The journal of Law and Economics 22, 233-261.

Williamson, O.E., 2000. The new institutional economics: taking stock, looking ahead. Journal of economic literature $38,595-613$.

Wilson, K.A., McBride, M.F., Bode, M., Possingham, H.P., 2006. Prioritizing global conservation efforts. Nature 440, 337.

Young, O.R., 2002. The institutional dimensions of environmental change: fit, interplay, and scale. MIT press. 